\title{
PERBANDINGAN TEKANAN INTRAOKULAR LATIHAN BENCHPRESS DAN BICEPS MASS ROUTINE POLA PROGRESSIVE OVERLOAD
}

\author{
Dian Eka Saputra ${ }^{1}$, Ardizal Rahman ${ }^{2}$, Andrini Ariesti ${ }^{3)}$. \\ ${ }^{1}$ Program Pendidikan Dokter Spesialis Ilmu Kesehatan Mata, Fakultas Kedokteran, Universitas Andalas, Asrama \\ Pemda Jl.Raya Aur Duri no.17 Padang \\ email: dianekasp@gmail.com \\ ${ }^{2}$ Bagian Ilmu Kesehatan Mata, Fakultas Kedokteran, Universitas Andalas, Jl.Tan Malaka no. 18 Sawahan, Padang \\ email: ardizalrahman@yahoo.com \\ ${ }^{3}$ Bagian Ilmu Kesehatan Mata, Fakultas Kedokteran, Universitas Andalas, Komplek Jondul V blok D-06, Parupuk \\ Tabing, Padang \\ email: andriniariesti@yahoo.co.id
}

Submitted : 13-04-2020, Reviewer:15-04-2020, Accepted: 20-04-2020

\begin{abstract}
Introduction : Weight training as an isometric exercise can increase intraocular pressure (IOP) during exercise. Several mechanism theories are proposed in analyzing IOP elevation in weight training. Increased intra-abdominal pressure increases intracranial pressure thereby increasing IOP. Another theory is the Valsalva maneuver which results in an increase in intrathoracic venous pressure that is transmitted to the veins leading to the ocular so that IOP increases. IOP elevations over a period of time are at risk of causing glaucoma and blindness.Method: This study's sample consisted of 62 students who were given biceps mass routine and benchpress training with 5 sets of progressive overload patterns. IOP values were measured before training, between sets and 30 minutes after rest using a non-contact tonometry.Result: There was a statistically significant correlation between the increase in IOP values between before exercise with the fifth set in the right eye lying position exercise $(10.323 \mathrm{~mm} H \mathrm{~g})$ and the left eye $(11.419 \mathrm{mmHg})$ to the increase in the IOP value before exercise with the fifth set in the sitting position of the right eye $(6,581 \mathrm{mmHg})$ and left eye $(7,435 \mathrm{mmHg})$.Conclusion: IOP values increase during weight training at both positions of the progressive overload pattern. The greater the training load the greater the IOP value. The lying down position gives the effect of increasing the greater IOP value.
\end{abstract}

Keywords: IOP, biceps mass routine, benchpress, progressive overload, valsava maneuver

\begin{abstract}
Abstrak
Pendahuluan : Latihan beban sebagai suatu latihan isometrik dapat meningkatkan tekanan intraokular (TIO) selama latihan. Beberapa teori mekanisme di ajukan dalam menganalisa peningkatan TIO pada latihan beban. Peningkatan tekanan intra abdominal meningkatkan tekanan intrakranial sehingga meningkatkan TIO. Teori lainnya berupa manuver Valsava yang mengakibatkan peningkatan tekanan vena intratorakal yang ditransmisikan ke vena-vena yang menuju okular sehingga terjadi peningkatan TIO. Peningkatan TIO dalam jangka waktu tertentu beresiko menyebabkan glaukoma dan kebutaan. Metode: Subjek penelitian ini terdiri dari 62 mahasiswa yang diberikan latihan beban posisi duduk (biceps mass routine) dan posisi berbaring (benchpress) dengan pola progressive overload masingmasing sebanyak 5 set. Nilai TIO diukur sebelum latihan, antar set dan 30 menit setelah istirahat menggunakan tonometri non kontak.
\end{abstract}


Hasil: Terdapat hubungan yang bermakna secara statistik perbandingan peningkatan nilai TIO antara sebelum latihan dengan set ke lima pada latihan posisi berbaring mata kanan (10,323 $\mathrm{mmHg}$ ) dan mata kiri $(11,419 \mathrm{mmHg})$ terhadap peningkatan nilai TIO sebelum latihan dengan set ke lima pada posisi duduk mata kanan $(6,581 \mathrm{mmHg})$ dan mata kiri $(7,435 \mathrm{mmHg})$. Kesimpulan: Nilai TIO meningkat selama latihan beban pada kedua posisi pola progressive overload. Semakin besar beban latihan semakin besar nilai TIO. Posisi latihan berbaring memberikan efek peningkatan nilai TIO yang lebih besar.

Kata Kunci: TIO, biceps mass routine, benchpress, progressive overload, manuver valsava.

\section{PENDAHULUAN}

Tekanan intraokular (TIO) adalah tekanan cairan di dalam bola mata yang nilainya ditentukan oleh kecepatan pembentukan akuos humor, sirkulasi dan tahanan terhadap aliran keluarnya akuos humor dari mata melalui jalur trabecular outflow dan uveoscleral outflow serta tekanan vena episklera . Peningkatan TIO dapat terjadi akibat peningkatan produksi ataupun gangguan aliran keluar dari akuos humor tersebut. Peningkatan volume vitreus, koroid, pembuluh darah serta peningkatan rigiditas sklera dan tekanan pada otot orbikularis juga berdampak terhadap peningkatan TIO. Peningkatan TIO dalam jangka waktu tertentu dapat menyebabkan terjadinya glaukoma. ${ }^{1,2}$

Glaukoma merupakan suatu grup penyakit dengan karakteristik neuropati optik yang sesuai dengan remodeling elemen jaringan ikat pada papil nervus optikus (dikenal sebagai diskus optikus) dan hilangnya jaringan syaraf yang berlanjut menjadi disfungsi penglihatan dengan pola yang khas akibat peningkatan TIO. Faktor risiko terjadinya glaukoma termasuk genetika, ras, usia, dan faktor vaskular., ${ }^{2,3,4}$

Olahraga telah lama diketahui mengurangi risiko berbagai penyakit. Olahraga mengurangi risiko terjadinya diabetes tipe 2 , hipertensi, dan berbagai keadaan patologi kardiovaskular. Olahraga yang teratur saat ini sudah menjadi suatu gaya hidup, terutama dikota-kota besar seiring dengan bertambahnya pusat kebugaran. Salah satu olahraga yang diminati pada saat ini adalah latihan beban yang banyak terdapat pada semua pusat kebugaran. Umumnya olahraga ini didominasi oleh laki-laki dewasa muda. ${ }^{5,6,7,8}$

Latihan beban sebagai suatu latihan isometrik pada beberapa penelitian diketahui dapat meningkatkan TIO selama latihan. Beberapa teori mekanisme di ajukan dalam menganalisa peningkatan TIO pada latihan beban. Peningkatan tekanan intra abdominal meningkatkan tekanan intrakranial sehingga meningkatkan TIO. Teori lainnya berupa manuver Valsava dimana pada latihan beban akibat peningkatan tekanan vena intratorakal yang ditransmisikan ke vena vorteks koroid, meningkatkan volume khoroid dan tekanan vena episklera sehingga terjadi peningkatan TIO. Posisi latihan juga mempengaruhi peningkatan TIO. Adapun posisi tubuh, TIO pada posisi berbaring lebih tinggi daripada duduk, dan mungkin perubahan hidrostatik seperti peningkatan tekanan vena episkleral yang terjadi dari satu posisi ke posisi lain dapat menjelaskan perbedaan tersebut. ${ }^{6,9,10}$

Terjadinya peningkatan TIO selama latihan beban yang lama harus diwaspadai. Peningkatan TIO dalam waktu yang lama dapat menimbulkan kerusakan nervus optikus dengan resiko terjadinya kebutaan akibat glaukoma...,11

Dickerman et al (1992) membandingkan latihan beban pada subjek dengan dan tanpa menahan napas. Pada penelitian tersebut menemukan peningkatan TIO lebih menonjol ketika subjek menahan nafas, sebesar $4.3 \pm 4.2$ $\mathrm{mmHg}$, daripada saat bernafas normal, sebesar $2.2 \pm 3.0 \mathrm{mmHg}$. Pada penelitian ini disimpulkan bahwa tekanan intraabdominal yang tinggi menyebabkan kemungkinan peningkatan tekanan intrakranial sehingga mengurangi aliran vena okular dan setidaknya berkontribusi pada peningkatan TIO pada subjek latihan beban yang pada dasarnya melakukan manuver Valsalva, meningkatkan TIO rata-rata $15 \mathrm{~mm} \mathrm{Hg}$ dengan 1 subjek mencapai TIO $46 \mathrm{~mm}$ Hg. ${ }^{12}$

Vieira et al (2006) melaporkan terjadinya peningkatan TIO yang signifikan sebagai efek akut dari latihan beban maksimal 4 kali repetisi pada mahasiswa yang sehat. Rata- 
rata nilai TIO pada kondisi beban maksimal setara $28.0+9.3 \mathrm{mmHg}$, dengan rerata peningkatan $15.0 \mathrm{mmHg}$. Peningkatan TIO pada latihan beban ini didasarkan pada teori peningkatan tekanan intraabdomen dan intratorakal, manuver Valsava dan usaha ekspiratori yang dilakukan oleh subjek dalam mengangkat beban. ${ }^{9}$

Singh et al (2007) melakukan penelitian efek latihan benchpress terhadap TIO kepada remaja usia 17-26 tahun. Pada penelitian tersebut ditemukan peningkatan TIO yang cukup bermakna $8,29 \pm 1.85 \mathrm{mmHg}$ pada kedua mata menggunakan metode beban maksimum sebanyak 4 repetisi. Namun data nilai TIO setelah latihan tidak diukur dalam penelitian tersebut. ${ }^{13}$

\section{METODE PENELITIAN}

Penelitian ini merupakan studi eksperimental analitik komparatif numerik berpasangan. Populasi penelitian ini adalah mahasiswa laki-laki Pendidikan Dokter Fakultas Kedokteran Universitas Andalas yang sedang menjalani kepaniteraan klinik di rumah sakit Dr.M Djamil Padang dan memenuhi kriteria inklusi penelitian. Semua subjek penelitian akan melakukan latihan beban posisi duduk (biceps routine) dan berbaring (benchpress). Pemilihan subyek berdasarkan purposive sampling. Perkiraan besar subjek minimum untuk setiap kelompok ditentukan dengan rumus penelitian analitik komparatif tidak berpasangan dengan jumlah 62 subjek.

Penelitian dilakukan di Poliklinik Mata RSUP Dr.M. Djamil Padang yang dilaksanakan November 2019 sampai dengan Desember 2019. Alat utama yang dibutuhkan berupa set beban berbagai ukuran dengan bar beban, bench latihan, alat timbangan badan, pengukur tinggi badan, slit lamp, funduskopi dan tonometer non kontak. Kriteria inklusi berupa :

1. Subjek penelitian adalah msahasiswa laki-laki Fakultas Kedokteran Universitas Andalas

2. Subjek penelitian menyatakan bersedia ikut serta dalam penelitian untuk menjadi subjek penelitian dan menyetujui pemeriksaan yang akan dilakukan.

3. Subjek dalam keadaan sehat

4. Tidak pernah melakukan latihan beban rutin

5. Tidak memiliki kelainan segmen anterior dan posterior pada kedua mata

6. Tidak memiliki riwayat peningkatan TIO atau pernah didiagnosa menderita glaukoma atau yang mendapat terapi anti glaukoma pada kedua mata

Kriteria eksklusi subjek pada penelitian ini berupa :

1. Subjek dalam keadaan demam.

2. Memiliki riwayat operasi mata (operasi kornea, operasi katarak, operasi glaukoma, operasi retina)

3. TIO terukur pada rentang $<10 \mathrm{mmHg}$ atau $>21 \mathrm{mmHg}$ pada kedua mata

4. Indeks massa tubuh $<20 \mathrm{~kg} / \mathrm{m}^{2}$ atau $>$ $25 \mathrm{~kg} / \mathrm{m}^{2}$

5. Memiliki disablitias anggota gerak atas dan bawah dan kelainan tulang belakang

6. Mengkonsumsi obat steroid.

7. Mengkonsumsi obat antikoagulan.

8. Tidak bisa menyelesaikan 5 set latihan beban biceps mass routine atau benchpress pola progressive overload

Definisi Operasional

1. Tekanan Intraokular :

a. Definisi : tekanan bola mata yang diukur menggunakan tonometri non kontak minimal 3 kali pengukuran dan kemudian dicatat nilai mediannya. Pemeriksaan dilakukan pada kedua mata subjek penelitian

b. Cara ukur : Mengukur besarnya tekanan intraokular pada mata dengan tonometer non kontak

c. Alat ukur : Tonometer non kontak

d. Hasil Ukur : dalam satuan $\mathrm{mmHg}$

e. Skala Ukur : Numerik

2. Beban latihan pola Progressive Overload :

a. Definisi : beban yang dapat diangkat dalam satu lingkup gerak sendi penuh satu kali angkat sebanyak 10 kali repetisi (repetisi maksimum) dengan penambahan beban sebanyak $2,5 \mathrm{~kg}$ untuk setiap set berikutnya 
dengan total penambahan beban pada set ke 5 adalah $10 \mathrm{~kg}$ dari beban awal.

b. Cara ukur : mengukur besarnya beban yang diberikan dalam kilogram, dimulai dengan $65 \%$ dari IMT (rumus diagram Holten), kemudian ditambahkan $2,5 \mathrm{~kg}$ pada set berikutnya .

c. Alat ukur : Timbangan

d. Hasil Ukur :

- Beban set 1:65\% x IMT

- $\quad$ Beban set 2 : beban set $1+2,5 \mathrm{~kg}$

- $\quad$ Beban set 3 : total beban set $2+2,5 \mathrm{~kg}$

- $\quad$ Beban set 4 : total beban set $3+2,5 \mathrm{~kg}$

- $\quad$ Beban set 5 : total beban set $4+2,5 \mathrm{~kg}$

e. Skala Ukur : Numerik

\section{Posisi Duduk :}

Definisi : Posisi latihan angkat beban pada keadaan duduk punggung lurus, dengan kedua siku bertumpu pada sandaran bench dan tangan memegang bar beban.

\section{Posisi berbaring}

Definisi : Posisi latihan angkat beban pada keadaan berbaring di atas bench dengan punggung lurus dan tungkai bawah tega lurus bertumpu pada lantai, dengan kedua lengan tegak lurus terhada dada dan kedua tangan memegang bar beban.

Setiap subjek pertama kali sebelum latihan akan diukur berat badan, tinggi badan, IMT, dan TIO kedua mata. Perlakuan latihan pertama semua subjek diberikan latihan beban dengan posisi duduk (biceps mass routine), dan 1 minggu setelah itu diberikan latihan beban dengan posisi berbarung (benchpress). Untuk menstandarisasi upaya yang dilakukan tanpa tergantung pada atribut fisik masing-masing subjek, kami menetapkan sebelumnya beban awal $65 \%$ dari indeks massa tubuh subjek, yang kemudian penambahan beban untuk set berikutnya diberikan dengan jumlah yang sama yaitu 2,5 $\mathrm{kg}$ untuk masing-masing subjek sehingga pengerahan tenaga kira-kira sama untuk semua subjek penelitian. Subjek penelitian juga diberikan rentang istirahat 1 minggu antara latihan posisi duduk dengan berbaring untuk meminimalisir efek muscle memory dan stress otot agar beban yang diberikan tidak mempengaruhi stimulasi manuver valsava.
Subjek akan melakukan latihan beban sebanyak 5 set, dimana setiap set nya 10 kali repetisi dan istirahat antar set 1,5 menit. Nilai TIO diukur segera setelah menyelesaikan setiap set dan 30 menit setelah selesai set ke 5. Data kemudian dicatat, dipresentasikan dalam bentuk tabel dan dianalisa dengan uji Repeated ANOVA dengan post hoc Bonferroni.

\section{HASIL}

Subjek penelitian eksperimental ini terdiri dari 62 orang mahasiwa Fakultas Kedokteran Universitas Andalas yang memenuhi kriteria inklusi dan eksklusi yang telah ditetapkan. Perlakuan latihan dan pengumpulan data dilakukan di Poliklinik Mata RSUP Dr M Djamil Padang.

Tabel 1. Karakteristik subjek penelitian berdasarkan usia dan koreksi tajam penglihatan

\begin{tabular}{lcc}
\hline Karakteristik & Frekuensi & Persentase \\
\hline Usia & & \\
21 & 1 & 1,61 \\
22 & 34 & 54,840 \\
23 & 26 & 42,936 \\
$25 \quad$ Tajam & & 1,61 \\
Koreksi Penglihatan & & \\
Tanpa kacamata & 55 & 88,7 \\
Dengan Kacamata & 7 & 11,3 \\
\hline
\end{tabular}

Usia mahasiswa FK Universitas Andalas yang menjadi subjek pada penelitian ini berkisar antara 21-25 tahun dengan rerata usia 22,45 tahun dan dominasi usia 22 tahun sebanyak 34 orang $(54,840 \%)$, usia 23 tahun sebanyak 26 orang $(41,936 \%)$ (Tabel 1$)$.

Semua subjek penelitian memiliki tajam penglihatan tanpa koreksi dan dengan koreksi 20/20. Dari total 62 subjek, 55 orang $(88,7 \%)$ memiliki tajam penglihatan tanpa koreksi 20/20, sedangkan 7 orang $(11,3 \%)$ visus 20/20 dicapai dengan koreksi kacamata (Tabel 1)

Sebelum diberikan perlakuan latihan beban posisi duduk (biceps mass routine) dan berbaring (benchpress), subjek dilakukan pengukuran berat badan dan tinggi badan untuk menentukan indeks massa tubuh (IMT). Rerata 
berat badan subjek penelitian ini $65,419 \pm 3,748$ $\mathrm{kg}$ dan rerata tinggi badan subjek 1,695 $\pm 0,130$ m (Tabel 1) Semua subjek penelitian yang memiliki rentang indeks massa tubuh (IMT) normal, rentang $20-25 \mathrm{~kg} / \mathrm{m}^{2}$. Rerata IMT pada penelitian ini adalah $23,195 \pm 1,007 \mathrm{~kg} / \mathrm{m}^{2}$ (Tabel 2).

Nilai IMT menjadi acuan pengukuran beban awal untuk latihan, dimana beban awal adalah 65\% dari IMT. Beban awal akan ditambahkan setiap set nya sebanyak $2,5 \mathrm{~kg}$ untuk menyesuaikan dengan pola progressive overload. Rerata beban awal yang diberikan pada subjek penelitian ini adalah 15,008 \pm 0,656 $\mathrm{kg}$ (Tabel 2)

Tabel 2. Karakteristik subjek penelitian berdasarkan rerata berat badan, tinggi badan, IMT dan beban awal latihan.

\begin{tabular}{lll}
\hline & Mean & SD* \\
\hline Berat badan $(\mathrm{kg})$ & 65,419 & 3,748 \\
Tinggi badan $(\mathrm{m})$ & 1,695 & 0,130 \\
Indeks Massa & 23,195 & 1,007 \\
Tubuh $\left(\mathrm{kg} / \mathrm{m}^{2}\right)$ & & 0,656 \\
Beban awal $(\mathrm{kg})$ & 15,008 & deviation atau \\
$\begin{array}{l}\text { Keterangan * : } \\
\text { simpangan baku }\end{array}$ & &
\end{tabular}

Penelitian eksperimental untuk menganalisa perubahan peningkatan TIO pada latihan beban posisi duduk (biceps mass routine) dan berbaring (benchpress) pola latihan progressive overload pada 62 subjek yang memenuhi kriteria inklusi dan ekslusi ini dilaksanakan di poliklinik Ilmu Kesehatan Mata RSUP Dr.M Djamil Padang. Seluruh subjek diberikan latihan dengan dua posisi berbeda dengan jarak latihan antara posisi selama 1 minggu.

Pengukuran TIO dengan tonometri non kontak dilakukan sebanyak 7 kali selama 1 sesi latihan, baik latihan posisi duduk (biceps mass routine) dan berbaring (benchpress). TIO diukur saat sebelum latihan, setelah set 1 , set 2 , set 3 set 4 , set 5 dan 30 menit setelah latihan. Data yang didapatkan dari penelitian ini berdistribusi normal dan homogen (lampiran) yang diuji dengan menggunakan statistik parametrik, yaitu
Repeated ANOVA dengan analisa post hoc Bonferroni

Tabel 3. Nilai TIO mata kanan selama latihan beban terhadap posisi duduk dan berbaring dengan nilai $\mathrm{P}<0,001$

\begin{tabular}{lllll}
\hline & $\begin{array}{l}\text { Mean } \\
\text { Posisi } \\
\text { Duduk }\end{array}$ & SD* & $\begin{array}{l}\text { Mean } \\
\text { Posisi } \\
\text { Berbar } \\
\text { ing }\end{array}$ & SD* \\
\hline $\begin{array}{lllll}\text { Pre } \\
\text { latihan }\end{array}$ & 14,258 & 1,129 & 14,354 & 1,009 \\
Set 1 & 14,919 & 1,232 & 16,048 & 1,165 \\
Set 2 & 16,032 & 1,366 & 18,032 & 1,492 \\
Set 3 & 17,516 & 1,575 & 20,225 & 1,805 \\
Set 4 & 19,016 & 1,937 & 22,516 & 2,163 \\
Set 5 & 20,838 & 2,233 & 24,677 & 2,366 \\
30 menit & 14,790 & 0,943 & 15,661 & 0,957 \\
istirahat & & & & \\
\hline
\end{tabular}

Keterangan * : Standart deviation atau simpangan baku

Tabel 3 memperlihatkan hasil uji repeated ANOVA rata-rata TIO mata kanan subjek antara latihan beban posisi duduk (biceps mass routine) dengan posisi berbaring (benchpress) pola latihan progressive overload. Dari tabel terlihat TIO pada saat latihan dengan posisi duduk hingga set ke 5 masih berada dalam rentang nilai normal TIO (rerata $20,838 \mathrm{mmHg}$ atau kurang dari $21 \mathrm{mmHg}$ dengan $\mathrm{SD} \pm 2,233$ ). Berbeda dengan latihan beban posisi berbaring, tampak peningkatan nilai TIO diatas rentang normal (lebih dari $21 \mathrm{mmHg}$ ) setelah set ke 4 dan ke 5 (rerata TIO 22,516 mmHg dengan SD $\pm 2,163$ ). Nilai TIO mata kanan setelah 5 set latihan tampak kembali mendekati nilai normal setelah 30 menit istirahat pada kedua posisi latihan $(14,258 \mathrm{mmHg}$ SD $\pm 1,129$ turun menjadi $14,790 \mathrm{mmHg} \mathrm{SD} \pm 0,943$ pada posisi duduk dan 14,354 mmHg SD \pm 1,009 menjadi 15,661 $\mathrm{mmHg}$ SD $\pm 0,957$ pada posisi berbaring). Penurunan nilai TIO setelah latihan terlihat lebih besar pada posisi berbaring $(24,677 \mathrm{mmHg}$ SD $\pm 2,366$ menjadi $15,661 \mathrm{mmHg} \mathrm{SD} \pm 0,957)$ dibandingkan posisi duduk $(20,838 \mathrm{mmHg} \mathrm{SD} \pm$ 2,233 menjadi $14,790 \mathrm{mmHg} \mathrm{SD} \pm 0,943$ ).

Tabel 4. Nilai TIO mata kiri selama latihan beban terhadap posisi duduk dan berbaring dengan nilai $\mathrm{P}<0,001$ 


\begin{tabular}{lllll}
\hline & $\begin{array}{l}\text { Mean } \\
\text { Posisi } \\
\text { Duduk }\end{array}$ & SD* & $\begin{array}{l}\text { Mean } \\
\text { Posisi } \\
\text { Berba- } \\
\text { ring }\end{array}$ & SD* \\
\hline $\begin{array}{l}\text { Pre } \\
\text { Latihan }\end{array}$ & 14,225 & 1,372 & 14,306 & 1,110 \\
Set 1 & 14,983 & 1,487 & 16,016 & 1,110 \\
Set 2 & 16,225 & 1,740 & 18,193 & 1,469 \\
Set 3 & 17,806 & 1,948 & 20,758 & 1,852 \\
Set 4 & 19,629 & 2,167 & 23,306 & 2,192 \\
Set 5 & 21,661 & 2,428 & 25,725 & 2,548 \\
30 menit & 14,774 & 1,136 & 15,225 & 0,998 \\
istirahat & & & & \\
\hline
\end{tabular}

Keterangan * : Standart deviation atau simpangan baku

Berdasarkan tabel 4 hasil uji repeated ANOVA rata-rata TIO mata kiri subjek antara latihan beban posisi duduk (biceps mass routine) dengan posisi berbaring (benchpress) pola latihan progressive overload, TIO pada saat latihan dengan posisi duduk terlihat sedikit meningkat diatas nilai normal pada set ke 5 (rerata $21,661 \mathrm{mmHg} \mathrm{SD} \pm 2,428$ ). Peningkatan nilai TIO mata kiri diatas rentang normal pada latihan beban posisi berbaring terjadi setelah set ke 4 hingga set ke 5 (rerata TIO 23,306 mmHg $\mathrm{SD} \pm 2,192$ dan $25,725 \mathrm{mmHg} \mathrm{SD} \pm 2,548$ ). Rerata nilai TIO mata kiri juga mengalami penurunan setelah 30 menit istirahat, 14,774 mmHg SD $\pm 1,136$ pada latihan beban posisi duduk dan 15,225 $\mathrm{mmHg} \mathrm{SD} \pm 0,998$ pada latihan beban posisi berbaring. Penurunan TIO mata kiri setelah latihan beban tampak lebih besar setelah latihan beban posisi berbaring $(25,725 \mathrm{mmHg}$ SD $\pm 2,548$ menjadi 15,225 $\mathrm{mmHg} \mathrm{SD} \pm 0,998$ ) dibandingkan posisi duduk $(21,661 \mathrm{mmHg}$ SD $\pm 2,428$ menjadi 14,774 $\mathrm{mmHg} \mathrm{SD} \pm 1,136$ )

Hasil uji repeated ANOVA dilanjutkan dengan uji post hoc Bonferroni yang tersaji dalam bentuk data tabel pairwise comparison. Dari hasil uji post hoc Bonferroni didapatkan rerata peningkatan TIO antar set dan perbandingan masing-masing set nya pada kelompok latihan posisi duduk (biceps mass routine) pola progressive overload mata kanan dan kiri (tabel 5 dan 6).

Tabel 5. Perbandingan perubahan TIO mata kanan selama latihan beban terhadap posisi dengan nilai $\mathrm{P}<0,001$

\begin{tabular}{|c|c|c|c|c|}
\hline & \multicolumn{2}{|c|}{$\begin{array}{l}\text { Posisi } \\
\text { duduk }\end{array}$} & \multicolumn{2}{|l|}{$\begin{array}{l}\text { Posisi } \\
\text { berbaring }\end{array}$} \\
\hline & MD* & Sig. ${ }^{a}$ & MD & Sig. ${ }^{a}$ \\
\hline $\begin{array}{l}\text { Pre latihan } \\
\text { dengan set } 1\end{array}$ &,$- 661^{*}$ & ,000 & $-1,694^{*}$ & , 000 \\
\hline $\begin{array}{l}\text { Set } 1 \text { dengan } \\
\text { set } 2\end{array}$ & $-1,113^{*}$ & ,000 & $-1,984^{*}$ & , 000 \\
\hline $\begin{array}{l}\text { Set } 2 \text { dengan } \\
\text { set } 3\end{array}$ & $-1,484^{*}$ &, 000 & $-2,194^{*}$ & ,000 \\
\hline $\begin{array}{l}\text { Set } 3 \text { dengan } \\
\text { set } 4\end{array}$ & $-1,500^{*}$ &, 000 & $-2,290^{*}$ &, 000 \\
\hline $\begin{array}{l}\text { Set } 4 \text { dengan } \\
\text { set } 5\end{array}$ & $-1,823^{*}$ & ,000 & $-2,161^{*}$ &, 000 \\
\hline $\begin{array}{l}\text { Set } 5 \text { dengan } \\
\text { post latihan }\end{array}$ & $6,048^{*}$ &, 000 & $9,016^{*}$ &, 000 \\
\hline $\begin{array}{l}\text { Pre latihan } \\
\text { dengan set } 5\end{array}$ & $-6,581^{*}$ &, 000 & $-10,323^{*}$ &, 000 \\
\hline $\begin{array}{l}\text { Pre latihan } \\
\text { dengan post } \\
\text { latihan }\end{array}$ &,$- 532^{*}$ & 0,043 & $-1,306^{*}$ & ,000 \\
\hline
\end{tabular}

Tabel 6. Perbandingan perubahan TIO mata kiri selama latihan beban terhadap posisi dengan nilai $\mathrm{P}<0,001$

\begin{tabular}{lllll} 
& \multicolumn{2}{l}{ Posisi duduk } & \multicolumn{2}{l}{ Posisi berbaring } \\
\cline { 2 - 5 } & MD* & Sig. $^{\text {a }}$ & MD & Sig. $^{\text {a }}$ \\
\hline $\begin{array}{l}\text { Pre latihan } \\
\text { dengan set 1 }\end{array}$ &,$- 758^{*}$ &, 000 & $-1,710^{*}$ &, 000 \\
$\begin{array}{l}\text { Set 1 dengan } \\
\text { set 2 }\end{array}$ & $-1,242^{*}$ &, 000 & $-2,177^{*}$ &, 000 \\
$\begin{array}{l}\text { Set 2 dengan } \\
\text { set 3 }\end{array}$ & $-1,581^{*}$ &, 000 & $-2,565^{*}$ &, 000 \\
$\begin{array}{l}\text { Set 3 dengan } \\
\text { set 4 }\end{array}$ & $-1,823^{*}$ &, 000 & $-2,548^{*}$ &, 000 \\
$\begin{array}{l}\text { Set 4 dengan } \\
\text { set 5 }\end{array}$ & $-2,032^{*}$ &, 000 & $-2,419^{*}$ &, 000 \\
$\begin{array}{l}\text { Set 5 dengan } \\
\text { post latihan }\end{array}$ & $6,887^{*}$ &, 000 & $10,500^{*}$ &, 000 \\
$\begin{array}{l}\text { Pre latihan } \\
\text { dengan set 5 }\end{array}$ & $-7,435^{*}$ &, 000 & $-11,419^{*}$ &, 000 \\
$\begin{array}{l}\text { Pre latihan } \\
\text { dengan post }\end{array}$ &,$- 548^{*}$ &, 043 &,$- 919^{*}$ &, 000 \\
\hline
\end{tabular}


latihan

*: Mean Difference

a : Adjustment for multiple comparisons : Bonferroni

Pada tabel 5 dan 6 tersaji data perbandingan nilai TIO mata kanan dan mata kiri antar set terhadap posisi latihan beban. Pada posisi latihan duduk dan berbaring baik untuk mata kanan dan kiri, terlihat peningkatan TIO yang paling besar antara nilai TIO sebelum latihan dengan nilai TIO set ke 5. Rerata peningkatan nilai TIO antara sebelum latihan dengan set ke 5 untuk mata kanan ; sebesar $6,581 \mathrm{mmHg}$ pada posisi duduk dan 10,323 mmHg pada posisi berbaring, dan mata kiri ; sebesar $7,435 \mathrm{mmHg}$ pada posisi duduk dan $11,419 \mathrm{mmHg}$ pada posisi berbaring. Hasil uji statistik menunjukkan terdapat hubungan yang bermakna terhadap peningkatan TIO antara sebelum latihan dengan set1, set 1 dengan set ke dua, set ke dua dengan set ke tiga, set ke tiga dengan set ke empat, set ke empat dengan set ke lima pada latihan beban posisi duduk dengan berbaring. Hasil uji statistik juga menunjukkan adanya hubungan yang bermakna terhadap penurunan TIO pada set ke lima dengan nilai TIO 30 menit setelah istirahat latihan, baik pada latihan posisi duduk dan berbaring.

\section{PEMBAHASAN}

Tekanan intraokular (TIO) di tentukan oleh produksi, sirkulasi dan drainase aquous humor melalui trabecular outflow dan uveoscleral outflow. Volume vitreous, volume pembuluh darah koroid, rigiditas sklera, rtekanan otot ekstraokular dan tekanan eksternal juga dapat memberikan efek terhadap nilai TIO. Selain itu, nilai TIO juga dapat bervariasi akibat beberapa faktor lainnya seperti irama sirkadian, posisi tubuh, olahraga, manuver valsava, tekanan darah, kegemukan dan lain sebagainya. ${ }^{11,14,15}$

Peningkatan TIO selama manuver Valsava dan selama latihan isometrik (latihan beban) maksimal telah dilaporkan, dan kesamaan antara latihan beban dan kinerja manuver Valsava memunculkan postulat bahwa peningkatan TIO dapat terjadi selama latihan latihan beban. Pada penelitian ini peneliti mensimulasikan manuver
Valsava yang terjadi selama angkat berat dengan pola latihan progressive overload dengan melakukan latihan beban posisi duduk (biceps mass routine) dan posisi berbaring benchpress) yang juga merupakan dua jenis latihan beban yang sangat populer dilakukan pada pusat kebugaran. ${ }^{6,9,10}$

Pada penelitian ini, semua subjek penelitian menunjukkan peningkatan TIO yang bervariasi selama latihan. Rata-rata nilai TIO terjadi peningkatan pada kedua posisi latihan. Rerata peningkatan nilai TIO antar set tidak terlalu besar, antara lebih dari $0,5 \mathrm{mmHg}$ hingga 2 mmHg antar set (tabel 5 dan tabel 6), namun secara statistik bermakna pada baik latihan beban posisi duduk (biceps mass routine) dan berbaring (benchpress) pola latihan progressive overload. Perbandingan rerata peningkatan nilai TIO mata kanan dan kiri pada latihan beban posisi duduk (biceps mass routine) dan berbaring (benchpress) pola latihan progressive overload ini paling besar antara nilai TIO sebelum latihan dengan nilai TIO setelah set ke 5 .

Hasil ini sesuai dengan penelitian oleh Vieira et al (2006). Pada penelitian tersebut, Vieira et al melaporkan terjadinya peningkatan TIO yang signifikan sebagai efek akut dari latihan beban maksimal 4 kali repetisi pada mahasiswa yang sehat. Rata-rata nilai TIO pada kondisi beban maksimal yang bisa diangkat setara $23.0 \pm 5,6 \mathrm{mmHg}$, dengan rerata peningkatan $4,3 \mathrm{mmHg} .{ }^{9}$

Sama halnya dengan hasil penelitian ini, hasil penelitian oleh Dickerman et al (1992) yang membandingkan latihan beban pada subjek dengan dan tanpa menahan napas juga menemukan peningkatan TIO lebih menonjol ketika subjek menahan nafas maksimal (manuver Valsava), sebesar $28 \pm 9,3 \mathrm{mmHg}$, daripada saat bernafas normal, sebesar $13 \pm 2,8$ mmHg. ${ }^{12}$

Manuver Valsava terjadi akibat pernafasan paksa (force expiration) terhadap glottis tertutup yang menyebabkan peningkatan tiba-tiba dalam tekanan intratorakal. Manuver Valsava terjadi selama batuk, muntah, mengangkat benda berat, 
dan memainkan alat musik tiup. Peningkatan TIO selama angkat berat mungkin merupakan hasil dari manuver Valsava akibat pernafasan paksa , yang, terkait dengan kontraksi otot perut dan dada sebagai kompensasi untuk menambah kekuatan otot torak dan abdomen dalam mengangkat beban, menyebabkan peningkatan ekstra pada tekanan vena intratorakal dan kompresi sistem vena intratorakal. Peningkatan tekanan vena intratorakal ditransmisikan melalui vena jugularis, orbital, dan vorteks ke koroid, menyebabkan pelebaran pembuluh darah, peningkatan volume koroid, dan peningkatan TIO. Mekanisme lain yang mungkin untuk peningkatan TIO adalah peningkatan tekanan vena episkleral, yang meningkat pada tingkat yang jauh lebih lambat daripada pelebaran koroid. Semakin besar beban yang diberikan, maka semakin besar terjadi penafasan paksa yang memaksa terjadinya manuver Valsava yang lebih besar untuk memberikan kekutan otor sehingga terjadi peningkatan TIO yang lebih besar. ${ }^{6,9,16,17}$

Peningkatan tekanan intraokular (TIO) adalah faktor risiko utama untuk terjadinya dan perkembangan glaukoma. Oleh karena itu, pengukuran TIO memberikan informasi penting tentang diagnosis glaukoma, menilai kemungkinan perkembangan, dan memantau respons klinis terhadap terapi. Nilai TIO bukan nilai tetap tetapi berfluktuasi seiring waktu. Meskipun telah ada sejumlah studi tentang fluktuasi TIO dan perkembangan glaukoma, apakah fluktuasi akut TIO merupakan faktor risiko independen untuk kerusakan dan perkembangan glaukoma masih kontroversial. $1,18,19,20$

Fluktuasi akut TIO dapat didefinisikan sebagai variasi TIO yang terjadi dalam periode waktu yang sangat singkat. Tidak ada bukti langsung bahwa fluktuasi akut dalam jangka pendek memiliki efek pada perkembangan glaukoma. Eksperimen hewan pada primata telah menunjukkan lonjakan TIO tinggi yang singkat selama gerakan sakadik, kedipan, dan penggosokan mata. Penelitian lain pada model hewan menunjukkan bahwa peningkatan TIO akut (walaupun tidak selalu instan) dapat menyebabkan deformasi struktural kepala saraf optik atau menginduksi perubahan fungsional yang diukur secara elektrofisiologis. Berdasarkan penelitian pada hewan ini, para ahli berspekulasi bahwa peningkatan TIO akut dapat memberikan efek terhadap mata yang rentan atau beresiko mengalami glaukoma. 1,18,19,20

Pada penelitian ini, perbandingan peningkatan nilai TIO antara sebelum latihan dengan set ke lima (tabel 5 dan 6) pada latihan posisi berbaring mata kanan $(10,323 \mathrm{mmHg})$ dan mata kiri $(11,419 \mathrm{mmHg})$ lebih besar dibandingkan peningkatan nilai TIO sebelum latihan dengan set ke lima pada posisi duduk mata kanan $(6,581 \mathrm{mmHg})$ dan mata kiri $(7,435 \mathrm{mmHg})$.

Hasil ini sesuai dengan yang ditemukan oleh Vera et al (2017). Pada penelitian tersebut meneliti efek akut latihan beban pada prajurit angkatan udara dengan indeks massa tubuh normal dengan usia $46 \pm 4.7$ tahun. Penelitian ini membandingkan peningkatan TIO pada latihan squat jump (latihan dinamik) dengan benchpress (latihan isometrik). Pada penelitian tersebut ditemukan peningkatan TIO yang lebih signifikan pada latihan benchpress, dengan kenaikan rerata $37 \%$ dari nilai TIO awal sebelum latihan. Peningkatan TIO yang lebih besar terjadi ketika subjek mengangkat beban yang lebih berat diikuti dengan usaha menahan nafas (manuver valsava). ${ }^{6}$

Singh et al (2007) juga melakukan penelitian efek latihan benchpress terhadap TIO kepada remaja usia 17-26 tahun. Pada penelitian tersebut ditemukan hasil yang sama dengan penelitian ini, terjadi peningkatan TIO yang cukup bermakna $7,49 \mathrm{mmHg}$ pada mata kanan dan $7,00 \mathrm{mmHg}$ pada mata kiri menggunakan metode beban maksimum sebanyak 6 repetisi. ${ }^{13}$

Peningkatan TIO yang lebih besar selama latihan posisi berbaring pada penelitian ini sesuai dengan teori efek hidrostatik, otot utama yang terlibat dan manuver Valsava yang terjadi. Posisi berbaring secara teori memberikan efek hidrostatik terhadap peningkatan TIO melalui peningkatan tekanan vena episkleral. Otot yang terlibat dalam latihan benchpress juga ikut memberikan efek peningkatan TIO yang lebih 
besar. Efek otot utama yang dilatih pada benchpress, yaitu otot pektoralis mayor ini juga akan memberikan efek langsung terhadap peningkatan tekanan intratorakal yang lebih besar yang akan mengkompresi sistem vena dan berujung peningkatan TIO. ${ }^{6,9,16,17}$

Hasil penelitian ini juga sebanding dengan hasil yang diteliti oleh Soares et al (2015). Pada penelitian tersebut dilaporkan TIO pada posisi berbaring dan posisi duduk tidak mengalami perbedaan yang signifikan. Namun perubahan yang signifikan akan terjadi apabila subjek melakukan latihan beban. TIO akan lebih tinggi bila latihan beban dilakukan pada posisi berbaring daripada duduk. ${ }^{10}$

Peningkatan nilai TIO juga dapat terjadi pada posisi berbaring atau tidur. Fluktuasi TIO akut ini bisa akibat variasi diurnal-nokturnal, atau fluktuasi nyctohemeral, mengacu pada variasi TIO yang terjadi selama satu hari dengan rentang normal $2-6 \mathrm{mmHg}$. Perubahan TIO diurnal mungkin sebagian dijelaskan oleh perubahan postur tubuh yang terkait dengan tekanan darah dan perubahan tekanan vena episkleral, fluktuasi diurnal pada kadar kortisol, variasi dalam produksi air, siklus lingkungan dan siklus gelap, dan mungkin pengaruh musiman. ${ }^{1,18,19,20}$

Pada penelitian ini, puncak perubahan TIO latihan beban berada pada set ke 5 (posisi duduk : mata kanan $6,581 \mathrm{mmHg}$, mata kiri $7,435 \mathrm{mmHg}$; posisi berbaring mata kanan $10,323 \mathrm{mmHg}$, mata kiri $11,419 \mathrm{mmHg}$ ). Secara teori latihan beban posisi duduk masih berada dalam ambang batas variasi diurnal, namun posisi latihan berbaring sudah melewati rentang normal variasi diurnal $>6 \mathrm{mmHg} .{ }^{21,22,23,24}$

Meskipun diketahui bahwa nilai TIO tertinggi biasanya terjadi pada malam hari, mungkin juga ada alasan mengapa perubahan TIO nokturnal mungkin tidak mempengaruhi kesehatan saraf optik. TIO nokturnal yang lebih tinggi pada manusia sebagian besar disebabkan oleh posisi tidur terlentang, dan peningkatan perfusi pada posisi terlentang dapat mengatasi peningkatan TIO. Peningkatan tekanan cairan serebrospinal (CSF) pada posisi terlentang juga dapat mengatasi tekanan yang disebabkan oleh peningkatan TIO dengan mengurangi gradien tekanan trans-laminasi. Sangat mungkin bahwa ada mekanisme homeostatis lain untuk mengimbangi bioritme teratur, seperti yang terjadi dengan TIO dan tekanan darah. ${ }^{1,18,19,20}$

Perubahan TIO diurnal atau nokturnal dikombinasikan dengan perubahan tekanan darah sistemik dan aliran darah okular dapat berperan dalam patogenesis glaukoma. Dengan demikian, fluktuasi TIO yang dikombinasikan dengan defisiensi aliran darah okular autoregulatori dapat merusak jaringan yang rentan terhadap perubahan tekanan perfusi okular. ${ }^{1,18,19,20}$

Penurunan nilai TIO yang tersaji pada tabel 1 dan 2 , baik pada posisi duduk dan berbaring pada kedua mata antara set ke 5 dengan setelah istirahat pada penelitian ini mengalami penurunan yang cukup signifikan. Pada latihan beban dengan posisi duduk, penurunan TIO antara set ke 5 dengan TIO setelah 30 menit istirahat mata kanan $(6,048 \mathrm{mmHg})$ dan mata kiri $(6,887 \mathrm{mmHg})$ lebih kecil dibandingkan dengan penurunan TIO antara set ke 5 dengan TIO setelah 30 menit istirahat mata kanan $(9,016 \mathrm{mmHg})$ dan mata kiri $(10,500 \mathrm{mmHg})$ pada latihan beban posisi berbaring.

Nilai TIO kedua mata pada latihan beban posisi duduk dan berbaring antara sebelum latihan dengan setelah 30 menit istirahat memberikan nilai yang hampir sama. Pada latihan beban posisi duduk, TIO sebelum latihan adalah $14,258 \mathrm{mmHg} \pm 1,129$ (mata kanan) dan $14,225 \mathrm{mmHg} \pm 1,372$ (mata kiri), sedangkan TIO setelah 30 menit istirahat adalah $14,790 \mathrm{mmHg} \pm 0,943$ (mata kanan) dan $14,774 \mathrm{mmHg} \pm 1,136$ (mata kiri). Untuk latihan beban posisi berbaring, TIO sebelum latihan adalah $14,354 \mathrm{mmHg} \pm 1,009$ (mata kanan) dan $14,306 \pm 1,110 \mathrm{mmHg}$ (mata kiri), sedangkan TIO setelah 30 menit istirahat adalah $15,661 \mathrm{mmHg} \pm 0,957$ (mata kanan) dan $15,225 \mathrm{mmHg} \pm 0,998$ (mata kiri).

Hasil penurunan nilai TIO setelah istirahat ini sama dengan hasil yang didapatkan oleh penelitian Avunduk et al (1999) yang 
melakukan penelitian dengan membandingkan penurunan TIO setelah latihan isometrik dan isokinetik (dinamik). Pada penelitian tersebut didapatkan dalam 15 menit TIO akan kembali normal (setara dengan nilai TIO sebelum latihan). ${ }^{18}$ Hasil ini sedikit berbeda dengan penelitian Najmanova et al yang melakukan pengukuran TIO setelah latihan beban. Pada penelitian tersebut ditemukan nilai TIO akan kembali normal setelah 30 menit latihan. ${ }^{25}$

Hasil penelitian ini juga sejalan dengan hasil penelitian Risner et al (2009) yang melakukan meneliti perbandingan antara efek latihan fisik dinamik dengan isometrik terhadap perubahan TIO. Pada penelitian tersebut, TIO setelah latihan baru kembali normal setelah 30 menit. $^{4}$

Efek penurunan TIO pada latihan beban setelah peridoe akut peningkatan TIO ini berdasarkan konsep dehidrasi dan kembali lancarnya aliran pembuluh darah, berkurangnya rigiditas sklera dan lancarnya aliran vena episklera. ${ }^{4,25,26,27}$

Variasi fluktuasi TIO secara fisiologis dapat terjadi dalam siklus ritmik teratur. Fluktuasi " $u p$ and down" dari nilai TIO adalah normal, dan mekanisme kompensasi tersedia untuk menjaga integritas jaringan. Jika keadaan seimbang ini terganggu oleh peningkatan TIO yang tidak teratur, atau jika mekanisme kompensasi normal yang terjadi salah, kerusakan saraf mata dapat lebih mungkin terjadi. Variabilitas jangka panjang dapat mengganggu mekanisme homeostatis. Fluktuasi IOP yang tidak teratur dan besar dapat menyebabkan "loading and unloading stress" sebagai lawan dari kondisi tekanan statis, sehingga jaringan tidak dapat mengkompensasinya dan kerusakan dapat terjadi. ${ }^{1,18,19,20}$

Dalam manajemen klinis pasien glaukoma, kontrol TIO berbasis kualitas mungkin lebih penting daripada pengurangan TIO berbasis kuantitas untuk lebih efektif mencegah progresifitas penyakit. Dalam kasus perkembangan glaukoma sudut terbuka primer (POAG) dalam praktik klinis, tidak hanya TIO rendah tetapi TIO konstan (stabil) mungkin penting untuk mengendalikan progresifitas penyakit. Mempertahankan TIO konstan sambil mengurangi fluktuasi peningkatan mungkin sama pentingnya dengan mempertahankan nilai TIO rendah dalam hal progresifitas penyakit. $2,6,9,10,11$

Berdasarkan penelitian ini dapat disimpulkan bahwa latihan beban baik posisi duduk maupun berbaring dapat meningkatkan TIO berdasarkan beban yaang dapat ditoleransi oleh individu hingga terjadi manuver Valsava yang akan memicu proses peningkatan TIO. Posisi latihan beban juga memberikan efek tambahan peningkatan TIO dibandingkan latihan beban posisi duduk dengan beban yang sama. $1,18,19,20$

Berdasarkan teori, peningkatan TIO pada latihan beban pada individu normal mungkin saja tidak memberikan efek terhadap kerusakan jaringan saraf okular karena sistem kompensasi autoregulasi jaringan, namun fluktuasi akut peningkatan TIO pada latihan beban ini dapat saja memeberikan efek yang merugikan bagi individu-individu yang memiliki resiko glaukoma ataupun individu yang sudah memiliki glaukoma. ${ }^{1,18,19,20}$

Kelemahan penelitian ini adalah pengukuran nilai TIO yang diukur beberapa detik setelah latihan. Bias pengukuran nilai TIO juga dapat terjadi akibat perubahan posisi terutama pada subjek penelitian yang melakukan latihan beban posisi berbaring yang diukur pada posisi duduk. Kelemahan lainnya adalah penelitian ini juga tidak meneliti perubahan TIO yang terjadi saat dilakukan latihan dengan beban maksimal.

\section{SIMPULAN}

Nilai TIO meningkat selama latihan beban dengan posisi duduk (biceps mass routine) dan berbaring (benchpress) pada pola latihan progressive overload. Semakin besar beban yang diberikan semakin besar nilai TIO dimana peningkatan TIO pada 5 set latihan beban posisi berbaring (benchpress) pola progressive overload pada penelitian ini menunjukkan rentang yang melebihi nilai normal variasi diurnal. Posisi latihan mempengaruhi perubahan nilai TIO. Latihan beban dengan posisi berbaring memberikan efek peningkatan nilai 
TIO yang lebih besar dibandingkan dengan latihan posisi duduk. Pada penelitian ini, nilai TIO latihan beban posisi duduk secara teori masih berada dalam ambang batas variasi diurnal, namun posisi latihan berbaring sudah melewati rentang normal variasi diurnal.

Fluktuasi peningkatan nilai TIO pada latihan beban bersifat akut, terutama akibat manuver Valsava yang terjadi sebagai upaya kompensasi untuk meningkatkan kekuatan otot. Peningkatan nilai TIO akut selama latihan beban dapat turun segera setelah latihan dihentikan dan istirahat.

\section{UCAPAN TERIMAKASIH}

Terimakasih kepada seluruh mahasiswa Fakultas Kedokteran Universitas Andalas, dan Bagian Ilmu Kesehatan Mata Fakultas Kedokteran Universitas Andalas/ RSUP DR.M.Djamil Padang.

\section{REFERENSI}

1. McMonnies CW. Intraocular Pressure and Glaucoma : Is Physical Excercise Beneficial or A Risk. Journal of Optometry. 2016;9:139-147.

2. Cantor LB, Rapuano JC, Cioffi GA. Introduction to Glaucoma : Terminology, epidemiology, and Heredity. American Academy of Ophthalmology Basic and Clinical Science Course Section 10 Glaucoma. 2014:3-13

3. Meier NF, Lee DC, Sui X, Blair SN. Physical Activity, Cardiorespiratory Fitness, and Incident Glaucoma. Official Journal of The American College of Sports Medicine. 2018:2253-2258.

4. Risner D, Ehrlich R, et al A. Effects of Excercise on Intraocular Pressure and Ocular Blood Flow. Journal Glaucoma. 2009;18(6):429-436

5. Gale J, Wells AP, Wilson G. Effects of Excercise on Ocular Physiology and Disease. Survey of Ophthalmology. 2009;54(3):349-355

6. Vera J, Garcia-Ramos A, et al. The Acute Effect of Strength Excercises at
Different Intensities on Intraocular Pressure. Graefes Archive Clinical Experimental Ophthalmology. 2017:1-7.

7. Rüfer F, Schiller J, Klettner A, et al. Comparison Of The Influence Of Aerobic And Resistance Exercise Of The Upper And Lower Limb On Intraocular Pressure. Acta Ophthalmologica. 2014;92:249-252.

8. Solberg PA, Kvamme NH, Raastad T, et al. Effects Of Different Types Of Exercise On Muscle Mass, Strength, Function And Wellbeing In Elderly. Europe Journal of Sport Science. 2013;13:112-125.

9. Vieira G, Oliveira H, de Andrade D, et al. Intraocular Pressure Variation During Weight Lifting. Archive Ophthalmology. 2006;124:1251-1254.

10. Soares AS, Caldara AA, et al. Variation of Intraocular Pressure in resistance Excercise Performed in Two Different Position. Rev Bras Oftalmol. 2015;74(3):160-163

11. Allingham RR, Damji KF, Freedman S, Moroi SE, Shafranov G. Cellular And Molecular Biology Of Aqueous Humor Dynamics. Shields' Textbook of Glaucoma ed 6th. Lippincott Williams and Wilkins. Philadelphia. 2011:5-33

12. Dickerman RD, Smith GH, LanghamRoof L, et al. Intraocular Pressure Changes During Maximal Isometric Contraction: Does This Reflect IntraCranial Pressure Or Retinal Venous Pressure? Neurol Res. 1999;21:243246.

13. Singh R, Madan R, et al. Impact during bench press excercise on intraocular pressure in young individual. IOSR journal of Dental and Medical Sciences. 2017;16(10):39-41.

14. Johnstone MA. Aqueous Humor Outflow System Overview. BeckerShaffer's Diagnosis and Therapy of The Glaucoma ed 8th. Ed: Stamper RL, 
Lieberman MF, Drake MV. Elsevier. 2009: $25-42$

15. Cantor LB, Rapuano JC, Cioffi GA. Intraocular Pressure and Aqueous Humor Dynamics. American Academy of Ophthalmology Basic and Clinical Science Course Section 10 Glaucoma. 2014:13-26

16. Avunduk AM, Yilmaz B, Sahin B, et al. The Comparizon of Intraocular Pressure Reduction after Isometric and Isokinetic Excercise in Normal Individuals. Ophthalmologica. 1999;213:290-294.

17. Singh RS, Madan R, Kaur S, Rani N. Impact During Bench Press Escercise on Intraocular Pressure in Young Individuals. IOSR Journal of Dental and Medical Science. 2017;16(10):39-41.

18. AGIS Investigators. The Advanced Glaucoma Intervention Study (AGIS): 7. The Relationship Between Control O Intraocular Pressure And Visual Field Deterioration. American Journal Ophthalmology. 2000;130:429-440.

19. McMonnies CW. Glaucoma History and Risk Factor. Journal of optometry. 2017; 10:71-78

20. Qureshi IA, Xi XR, Wu XD, et al. The Effect Of Physical Fitness On Intraocular Pressure In Chinese Medical Students. Zhonghua Yi Xue Za Zhi (Taipei). 1996;58:317-322.

21. Le A, Mukesh BN, McCarty CA, Taylor HR. Risk Factors Associated With The Incidence Of Open-Angle Glaucoma: The Visual Impairment Project. Invest Ophthalmol Vis Sci. 2003;44:3783-3789

22. Fulop T, Larbi A, Witkowski JM, et al. Aging, Frailty and Age-related Diseases. Biogerontology. 2010;11:547-563.

23. Rudnicka AR, Mt-Isa S, Owen CG, Cook DG, Ashby D. Variations In Primary Open-Angle Glaucoma Prevalence By Age, Gender, And Race: A Bayesian Meta-Analysis. Invest Ophthalmol Vis Sci.2006;47:4254-4261.
24. Vajaranant TS, Nayak S, Wilensky JT, Joslin CE. Gender And Glaucoma: What We Know And What We Don't Know. Current Opinion in Ophthalmology. 2010;21:91-99.

25. Najmanova E, Pluhacek F, Botek M. Intraocular Pressure Response to Moderate Excercise during 30-min Recovery. Optometry and Visiion Science. 2016;93(3):281-285

26. Marcus DF, Krupin T, Podos SM, et al. The Effect Of Exercise On Intraocular Pressure. I. Human Beings. Invest Ophthalmol Vis Sci. 1970;9:749-752.

27. Brody S, Erb C, Veit R, et al. Intraocular pressure changes: the influence of psychological stress and the Valsalva maneuver. Biol Psychol. 1999;51:43-57. 